\title{
Attitudes Toward Same-Gender Adoption and Parenting: An Analysis of Surveys from 16 Countries
}

\section{Darrel Montero}

\begin{abstract}
Globally, little progress has been made toward the legalization of same-gender adoption. Of the nearly 200 United Nations members, only 15 countries with populations of 3 million or more have approved LGBT adoption without restrictions. The objectives of this paper are, first, to provide a brief background of the obstacles confronting samegender adoption including the role of adoption agencies and parenting issues; second, to discuss the current legal status of the 15 countries which have approved same-gender adoption without restrictions; third, to report on recent public opinion regarding the legalization of same-gender adoption and parenting, drawing from previously published surveys conducted in 16 countries; and, fourth, to explore the implications for social work practice including social advocacy and social policy implementation.
\end{abstract}

Keywords: Same-gender adoption, same-sex adoption, gay adoption, same-gender parenting

To date, few papers have addressed the issue of same-gender adoption globally. As of 2013, only 15 major industrialized countries have approved same-gender adoption without restrictions. For the purpose of this paper, the term "without restrictions" refers to nations which allow joint adoption by same-gender couples, step-parent adoption (of their same-gender partner's biological child), and adoption by a single gay or lesbian individual. Although Canada was the first country to approve same-gender adoption in 1999, the vast majority have only recently approved full legal adoption rights. The objectives of this paper are, first, to provide a brief background of the obstacles confronting same-gender adoption including the role of adoption agencies and parenting issues; second, to discuss the current legal status of the 15 countries which have approved same-gender adoption without restrictions; third, to report on recent public opinion regarding the legalization of same-gender adoption and parenting, drawing from previously published surveys conducted in 16 countries; and, fourth, to explore the implications for social work practice including social advocacy and social policy implementation.

It was not until 2011 that the United Nations Human Rights Council passed its first resolution recognizing lesbian, gay, bisexual, and transgender (LGBT) rights, urging all countries to enact laws protecting basic LGBT civil liberties (Dougherty, 2011). Laws affecting LGBT people vary greatly from country to country, ranging from full legal recognition of marriage, adoption, employment, and full civil liberties to the criminalization of consensual same-gender relationships in 76 countries (Council for Global Equality, 2011; United Nations Human Rights, 2013).

\footnotetext{
Darrel Montero, Ph.D., was an Associate Professor in the School of Social Work at Arizona State University in Phoenix. The author wished to thank the following organizations for their generosity in allowing the use of their survey data: Ipsos Global@dvisor conducted between and on behalf of Reuters News via the Ipsos Online Panel system (Ipsos/Reuters).
} 
Historically, the first country to approve same-gender adoption without restrictions was Canada in 1999. This was followed by the Netherlands (2001), South Africa (2002), and Sweden (2002). Most recently, on May 18, 2013, the French government approved same-gender marriage and adoption, despite France's long religious tradition of opposition to this policy. The legislation is cited as the country's most extensive social amendment since bringing an end to the death penalty in 1981 (Cody, 2013).

A wide range of international landmark legislation has marked a turning point for gay and lesbian couples who wish to adopt. Namely, in England and Wales, the Adoption and Children Act of 2002 allowed for gay and lesbian couples wishing to adopt children (Brodzinsky, 2005). However, it was not until 2005 that this Act came into full effect and permitted same-gender couples the right to adopt children (Logan \& Sellick, 2007). In 2007, The Equality Act (Sexual Orientation) Regulations further mandated that lesbian and gay couples cannot be discriminated against by adoption agencies (Samuel, 2010).

\section{Agency Constraints and Successes in Policy Implementation}

Although public and faith-based adoption agencies are required by law to comply with same-gender adoption statutes, there are numerous documented cases where agencies have chosen to disregard these laws. In the United States, where same-gender adoption is legal in some states, there have been cases of faith-based adoption agencies in Boston, Denver, the District of Columbia, and Rockford, Illinois which decided to close their doors rather than be forced to comply with same-gender adoption laws ("Catholic Adoption," 2011; Filteau, 2006; Kyle, 2013; "Same-Sex," 2010). Institutionalized bias against the LGBT community still can influence judges, legislators, casework experts, and individuals involved in the adoption process (Brodzinsky, 2003).

In England, some adoption agencies have witnessed targeted prejudice towards LGBT adoption, where adoption specialists were giving priority to heterosexual adoptive parents over homosexual parents (Doughty, 2011; English, 2012; Seal, 2009). Seal (2009) reported data regarding gay men who had adopted children, and found that some adoption workers gave preferential treatment to wealthy married heterosexual couples over single gay men.

As a result of England's 2007 Sexual Orientation Regulations, although some faithbased adoption agencies have stopped discriminating practices, others have ended their association with the church (Doughty, 2011). Britain's Catholic adoption society reported that they would close their doors if they were required to place orphans with same-gender couples ("Catholic," 2010). Moreover, the Muslim Council of Britain also sided with the Catholic Church and its adoption agencies ("Muslims," 2012).

Because of some of these selective practices, in England and Wales, the National Minimum Standards for Local Authority Adoption Services have established guidelines that require reasonable practices within British adoption agencies. These guidelines provide that adoptive parents are to be treated fairly, with respect, and without prejudice (Department of Education, 2011). 
In 2008, the European Court of Human Rights ruled that same-gender couples can adopt. Their ruling prohibited the exclusion of gay individuals or couples from applying for adoption. The court concluded that the best interest of the child is of utmost importance, adding that prejudice based on sexual orientation should not stand in the way of care and love ("Europe," 2008).

In 2013, a same-gender couple from Austria sought to adopt a partner's biological son. The jury believed the couple and child were a family, citing that same-gender parents are no more harmful to children than heterosexual parents. Leaders of both Amnesty International and the International Lesbian, Gay, Bisexual, Transgender, and Intersex Association stated that they hoped the judgment furthered equality for European families (Cassell, 2013).

In February 2013, Puerto Rico's Supreme Court upheld a law prohibiting samegender couples from adopting. Also in February, the Federal Constitutional Court of Germany ruled that same-gender couples in a civil union can legally adopt their partner's non-biological child/ren. In May, Portugal's Parliament voted to approve a law allowing same-gender couples to adopt their partners' children. As well, in October the Northern Ireland High Court maintained that a law allowing adoption only by heterosexual married couples or single individuals is illegal, regardless of their sexual orientation (Franklin, 2013).

However, opposition of same-gender rights and adoption is still prevalent, and it remains quite difficult for same-gender couples to pursue adoption globally. Prejudice against LGBT people is rampant in many countries with large orphan populations. As such, overt policies and/or implied social attitudes exist against same-gender adoption. Even the most forward-thinking adoption agencies are cautious about representing samegender adopters due to the challenges of working with anti-gay policies and laws (Levine, 2013).

Recently, perhaps the strongest anti-gay response has been by Vladimir Putin. In 2012, the Russian lower house of parliament prohibited the adoption of orphans by samegender couples from countries where same-gender marriage is legal (Franklin, 2013). In addition, in 2013, Putin's anti-LGBT campaign continued by levying a $\$ 3,000$ fine against any Russian citizen who advocates for LGBT rights (Gessen, 2013). UNICEF estimates that there are approximately 740,000 Russian children in need of adoption, while only about 18,000 Russian parents are seeking to adopt (Heintz, 2012).

\section{Same-Gender Parenting}

A serious roadblock facing same-gender couples seeking to adopt is the issue posed by some critics as to whether LGBT parents can offer the same quality of parenting as heterosexual parents (Erich, Leung, \& Kindle, 2005; Erich, Leung, Kindle, \& Carter, 2005). However, there is substantial evidence that underscores the merits of and successes found in LGBT parenting. After reviewing the scientific literature, three major professional associations-The American Psychological Association ([APA], 2010), Australian Psychological Society ([APS], Short, Riggs, Perlesz, Brown, \& Kane, 2007), and Canadian Psychological Association ([CPA], 2006) - came to the conclusion that the 
well-being of children with same-gender parents does not vary from that of children with heterosexual parents.

The CPA (2006) based their position on a review of over 100 empirical studies. An analysis of this research suggests no consistent differences between the mental health and social personality of children raised by same-gender or heterosexual parents ("Brief," 2005). The Australian Psychological Society (Short et al., 2007) indicated that their research showed that same-gender parenting and their children's outcomes are likely to be at least as favorable as those in families of heterosexual parents.

Numerous studies conducted from 1995 through 2013 underscore the conclusions reported by the APA, APS, and CPA (Anderssen, Amlie, \& Ytteroy, 2002; Biblarz \& Savci, 2010; Bos, Gartrell, \& van Gelderen, 2013; Bos, Gartrell, Peyser, \& van Balen, 2008; Bos, Gartrell, Roeleveld, \& Ledoux, 2013; Chan, Raboy, \& Patterson, 1998; Cianciaruso, 2013; Flaks, Ficher, Masterpasqua, \& Joseph, 1995; Goldberg \& Smith, 2013; Golombok et al., 2003; Golombok et al., 2013; Patterson, 2008; Perrin, 2013; Tasker \& Golombok, 1995; Veldorale-Brogan, 2012; Wainwright, Russell, \& Patterson, 2004). Similar policy statements have been advanced by an additional 14 professional groups regarding the viability of gay/lesbian adoption and parenthood. These professional associations include the American Academy of Child and Adolescent Psychiatry, American Academy of Family Physicians, American Academy of Pediatrics, the American Association for Marriage and Family Therapy, American Bar Association, American Medical Association, the American Psychiatric Association, the American Psychoanalytic Association, the American Sociological Association, the Child Welfare League of America, the National Adoption Center, the National Association of Social Workers, the North American Council on Adoptable Children, and Voice for Adoption.

\section{Methods}

The findings of this study are based on previously published opinion polls from Ipsos Global @dvisor (2013) conducted between and on behalf of Reuters News via the Ipsos Online Panel system in the following countries: Argentina, Australia, Belgium, Canada, France, Germany, Great Britain, Hungary, Italy, Japan, Norway, Poland, South Korea, Spain, Sweden and the United States of America. An international sample of 12,484 adults aged 18-64 in the U.S. and Canada (and aged 16-64 in all other countries) were interviewed.

The Ipsos Global @dvisor (2013) conducts attitudinal surveys internationally on a regular basis. The purpose of the present study is to report a subset of the data this organization collected in its 2013 survey. Numerous questions were asked by the organization on same-gender issues; however, these were not relevant to this article's specific focus on same-gender adoption. Within this context, I report the survey methodology below used by the Ipsos Global@dvisor.

Approximately 1,000 individuals participated on a country-by-country basis, except in Argentina, Hungary, Norway, Poland, South Korea and Sweden where each nation had a sample of approximately 500 respondents. Weighting was then used to balance demographics and make certain that the sample reflected that of the adult population 
according to the most recent country census data and to present results intended to estimate the sample universe. The accuracy of Ipsos polls is calculated by using a confidence interval ( 1,000 is accurate to $+/-3.5$ percentage points, while a poll of 500 is accurate to $+/-5.0$ percentage points in their respective general populations). All sample surveys and polls may be subject to other sources of error, including but not limited to coverage error and measurement error. Additional information and parameters on confidence intervals and research methodology can be found on the Ipsos Public Affairs (2013) website.

\section{Limitations}

Numerous scholars have reported the limits of survey research methodology (Creswell, 2013; Groves et al., 2013). As with all sample surveys, standard errors may include but are not limited to sampling errors, interviewer bias, nonresponse rate, social desirability response bias, types of survey questions (open-ended vs. closed-ended), and inter-rater reliability. The results may be impacted by the use of various terms to describe same-gender adoption (gay adoption, same-sex adoption, LGBT adoption, etc.). Also, as is typical of survey data, results can vary by a country's political climate, a newsworthy event, or a declaration from a major political or religious figure on same-gender adoption.

In examining the question in Table 2 ("Do you think same-sex couples should have the same rights to adopt children as heterosexual couples do?"), perhaps if the question was worded using the term "same-gender couples," "gay couples," or "gay individual" instead of "same-sex couples," it may have produced different responses. Similarly, in Table 3, the question reads: "Do you think same-sex couples are just as likely as other parents to successfully raise children?" If the second survey used the phrase "effectively raised children," it again may have produced different responses than what were reported here. Finally, in both surveys, there could be potential ambiguity or loss of uniformity due to the questions being asked in different languages. Thus, "same-gender couple" may not translate into a "gay or lesbian couple" as in the English language. Despite these limitations, it is important for researchers to make an effort to report disparate global surveys and determine where the citizens of these 16 countries stand on their support or lack of support for the legalization of same-gender adoption and their views on parenting.

\section{Results}

\section{Countries That Have Approved Same-Gender Adoption With No Restrictions}

As of November 2013, 15 countries have approved same-gender adoption without restrictions (see Table 1). Countries without restrictions refer to nations that allow joint adoption by same-gender couples, step-parent adoption, and adoption by a single gay or lesbian individual. Canada was the pioneer country approving same-gender adoption in 1999, followed by the Netherlands in 2001 and South Africa and Sweden in 2002. Most recently, France approved same-gender adoption without restrictions in 2013. Of the 15 countries that have approved same-gender adoption without restrictions, two thirds of these nations are located in Western Europe. The remaining five countries are found in 
South America (Argentina, Brazil, and Uruguay), North America (Canada), and Africa (South Africa).

Table 1. Countries That Have Approved Same-Gender Adoption With No Restrictions

\begin{tabular}{lcc}
\hline Country & Legalized & Population (approximate in millions) \\
Argentina & 2010 & $41 \mathrm{M}$ \\
Belgium & 2006 & $11 \mathrm{M}$ \\
Brazil & 2010 & $198 \mathrm{M}$ \\
Canada & 1999 & $34 \mathrm{M}$ \\
Denmark & 2010 & $6 \mathrm{M}$ \\
England & 2005 & $53 \mathrm{M}$ \\
France & 2013 & $66 \mathrm{M}$ \\
Netherlands & 2001 & $17 \mathrm{M}$ \\
Norway & 2009 & $5 \mathrm{M}$ \\
Scotland & 2009 & $5.5 \mathrm{M}$ \\
South Africa & 2002 & $51 \mathrm{M}$ \\
Spain & 2005 & $47 \mathrm{M}$ \\
Sweden & 2002 & $10 \mathrm{M}$ \\
Uruguay & 2009 & $3.5 \mathrm{M}$ \\
Wales & 2005 & $3 \mathrm{M}$ \\
\end{tabular}

Sources: Begley, 2013; “Ultimate Gay Adoption Guide,” 2013.

Note: Upon initially focusing on the topic of same-gender adoption globally, the author was immediately confronted with the need to make the conceptual decision of how to organize the nearly 60 countries and jurisdictions that have approved some form of same-gender adoption. Therefore, a decision was made to include countries based on three criteria that were met in 2013: (a) countries that have approved same-gender adoption with no restrictions - that is, nations which allow joint adoption by same-gender couples, stepparent adoption, and adoption by a single gay or lesbian individual; (b) countries with populations of 3 million or greater; and (c) countries in which every state, province, or territory approves same-gender adoption without restrictions. Following the above criteria, although Andorra and Iceland met the no restrictions criterion, they did not meet the population threshold. In addition, although Australia, Mexico, and the United States met the population threshold, these countries were excluded because not every state and/or territory has approved same-gender adoption without restrictions.

Note: Only countries with populations of 3 million or greater are included in this table since many countries with populations below 3 million are often geographically quite small and consequently unknown to many readers. For example, French Guiana is 32,253 square miles with a population of approximately 250,000 , while Malta is 122 square miles and has a population of approximately 418,000 .

\section{Attitudes Toward Same-Gender Couples' Right to Adopt Children}

Ipsos Global@dvisor (2013) conducted an attitudinal study in 16 nations and asked a cross section of respondents the following question: "Do you think same-sex couples should have the same rights to adopt children as heterosexual couples do?" Table 2 
reports a breakdown of the responses for each country from greatest to least support for same-gender adoption. Column 3 reports "total agree," which is the combined responses of columns 1 and 2, "somewhat agree" and "strongly agree," respectively.

Table 2. Attitudes Toward Same-Gender Couples’ Right to Adopt Children, 2013

\begin{tabular}{|c|c|c|c|}
\hline & $\underline{\text { Somewhat Agree }}$ & $\underline{\text { Strongly Agree }}$ & $\underline{\text { Total Agree }}$ \\
\hline Sweden & $22 \%$ & $56 \%$ & $78 \%$ \\
\hline Spain & $20 \%$ & $52 \%$ & $73 \%$ \\
\hline Germany & $33 \%$ & $37 \%$ & $71 \%$ \\
\hline Canada & $25 \%$ & $45 \%$ & $70 \%$ \\
\hline Australia & $30 \%$ & $37 \%$ & $67 \%$ \\
\hline Belgium & $26 \%$ & $41 \%$ & $67 \%$ \\
\hline Norway & $26 \%$ & $41 \%$ & $67 \%$ \\
\hline Great Britain & $31 \%$ & $34 \%$ & $65 \%$ \\
\hline United States & $26 \%$ & $38 \%$ & $64 \%$ \\
\hline Japan & $45 \%$ & $15 \%$ & $59 \%$ \\
\hline France & $22 \%$ & $31 \%$ & $53 \%$ \\
\hline Argentina & $19 \%$ & $33 \%$ & $52 \%$ \\
\hline South Korea & $35 \%$ & $11 \%$ & $46 \%$ \\
\hline Hungary & $24 \%$ & $18 \%$ & $42 \%$ \\
\hline Italy & $22 \%$ & $19 \%$ & $42 \%$ \\
\hline Poland & $14 \%$ & $13 \%$ & $27 \%$ \\
\hline
\end{tabular}

Question: "Do you think same-sex couples should have the same rights to adopt children as heterosexual couples do?"

Note: Columns 1 and 2 may not total Column 3 because of rounding.

Source: Ipsos Global@dvisor (2013).

Of the 16 nations surveyed, 12 countries reported that a majority of the respondents interviewed agreed that same-gender couples should have the right to adopt. Canada, Germany, Spain, and Sweden report the greatest support, with more than 7 in 10 of their citizens supporting adoption. The four countries that fell below a majority ranged from $27 \%$ (Poland), with the remaining three countries of Italy, Hungary, and South Korea at approximately $40 \%$. It is interesting to note that two counties in particular reported large differences between "strongly agree" and "somewhat agree" response categories. In Japan, for example, 59\% reported "total agree," yet only 15\% "strongly agreed" on the proposition of same-gender adoption. Similar findings were reported for South Korea, where a near majority (46\%) answered "total agree," while only $11 \%$ reported "strongly agree." 


\section{Attitudes Toward Same-Gender Couples to Successfully Raise Children}

In 2013, Ipsos Global @dvisor also surveyed the same 16 countries and asked a cross section of respondents the following question: "Do you think same-sex couples are just as likely as other parents to successfully raise children?" Table 3 reports a breakdown of the responses for each country from greatest to least support that same-gender parents can successfully raise children. Just as in Table 2, column 3 reports "total agree," which is the combined responses of columns 1 and 2, "somewhat agree" and "strongly agree," respectively.

Table 3. Attitudes Toward Same-Gender Couples to Successfully Raise Children, 2013

\begin{tabular}{lccc}
\hline & Somewhat Agree & Strongly Agree & Total Agree \\
Sweden & $24 \%$ & $57 \%$ & $81 \%$ \\
Norway & $25 \%$ & $55 \%$ & $79 \%$ \\
Canada & $28 \%$ & $48 \%$ & $76 \%$ \\
Germany & $32 \%$ & $42 \%$ & $74 \%$ \\
Spain & $24 \%$ & $49 \%$ & $73 \%$ \\
Australia & $30 \%$ & $42 \%$ & $72 \%$ \\
Great Britain & $35 \%$ & $37 \%$ & $72 \%$ \\
Belgium & $28 \%$ & $42 \%$ & $70 \%$ \\
United States & $26 \%$ & $39 \%$ & $66 \%$ \\
France & $25 \%$ & $39 \%$ & $63 \%$ \\
Japan & $46 \%$ & $15 \%$ & $62 \%$ \\
Argentina & $24 \%$ & $34 \%$ & $59 \%$ \\
Italy & $26 \%$ & $24 \%$ & $49 \%$ \\
Hungary & $29 \%$ & $17 \%$ & $46 \%$ \\
South Korea & $36 \%$ & $6 \%$ & $42 \%$ \\
Poland & $22 \%$ & $15 \%$ & $36 \%$ \\
\hline
\end{tabular}

Question: "Do you think same-sex couples are just as likely as other parents to successfully raise children?"

Note: Columns 1 and 2 may not total Column 3 because of rounding.

Source: Ipsos Global @dvisor (2013).

Overall, for 12 of the 16 countries surveyed, a majority $(51 \%+)$ supported the successful raising of children by same-gender parents. In fact, for 8 of the 16 nations, support for same-gender couples' ability to successfully parent reached $70 \%$ or greater. Swedes offered the greatest support on this issue, where more than 8 in 10 agree that same-gender couples can successfully raise children.

Of the four countries where a majority did not support parenting by same-gender couples, the same four countries - Italy, Hungary, South Korea, and Poland - also did not support the right to adopt by same-gender couples at a majority or higher level. Japan and 
South Korea stood out, given that in both cases a very small percentage reported "strongly agree" when asked about the ability of successfully raising children by samegender couples. Finally, Polish respondents reported the lowest support on this issue (slightly more than 1 in 3 ).

\section{Discussion}

Of the nearly 200 members of the United Nations, only 15 countries have legalized same-gender adoption with no restrictions. An important pattern emerges among these countries: two-thirds of these nations are located in Western Europe. For decades, scholars have documented the origins and traditions of liberalism in this part of the world (de Ruggiero, 1977; Hlousek \& Kopecek, 2010; Kirchner, 1999; Leroux, 2011; Moravcsik, 1995). Their observations may, in part, explain the tolerance of these countries toward the issues faced by their LGBT citizens.

In 2013, attitudinal surveys conducted in 16 nations indicate that a majority of these countries report support for same-gender adoption and recognize same-gender couples' ability to successfully raise children. As noted earlier, regarding same-gender parenting, there is a large body of empirical studies which indicate that parenting by same-gender couples is equally successful when compared with heterosexual child-rearing. Given the findings that public opinion impacts social policy formation (Burstein, 2003; Kenworthy, 2009; Silver, 2013), we may anticipate more countries approving same-gender adoption in the future.

\section{Social Work Practice}

Even though numerous countries have prohibited discrimination against same-gender adoption, traditional attitudes and perhaps prejudice may still remain. Therefore, it is important for social workers to make their clients aware of international adoption laws which allow for placements based on cultural values as well as what is in the best interest of the child ("Adoption," 2013).

The results from these public opinion surveys may be useful for social workers who seek to advance social justice for their same-gender clients seeking to adopt (National Association of Social Workers, 2012). Globally, social workers who provide services to same-gender couples work in one of four distinct types of regions: Group 1 includes those 76 countries where consensual same-gender relationships are criminalized; Group 2 includes countries where homosexuality is not criminalized, yet full equal rights for members of the LGBT community are not granted; Group 3 countries and jurisdictions (dependencies, municipalities, and territories) have legalized same-gender adoption with restrictions; and Group 4 countries have legalized same-gender adoption without restrictions. We discuss the role for social workers practicing in each of these four environments.

First, social workers who work with LGBT clients in Group 1 countries where homosexuality is criminalized have the most challenging role when working with clients whose sexual preference is considered a crime. For instance, Uganda, Sierra Leone, and Senegal have declared homosexual acts illegal and anyone caught can be punished with 
long jail sentences ("Amnesty International," 2013). Consequently, these social workers may themselves encounter personal harm working with a member of the LGBT community. Within this context, they may need the support of organizations such as Amnesty International and United Nations Human Rights Council, as well as the larger global social work community, in seeking to reverse the criminalization of homosexuality. As a priority, these social workers need to work to decriminalize homosexuality before they can advocate for the possibility of marriage equality.

Group 2 countries include those where consensual same-gender relationships are not criminalized, yet basic civil rights have not been granted. Social workers will need to advocate for their clients' rights in terms of civil unions, adoption, and employment.

Group 3 includes countries and jurisdictions that have endorsed some form of legal same-gender adoption but with restrictions. In this context, social workers have important roles in both direct practice and macro practice. First, in direct practice, social workers will work with clients who seek full equality adoption rights currently enjoyed by their counterparts in only 15 countries. A critical role for social workers at the macro level will be to engage in social action and policy implementation to bring about the legalization of same-gender adoption. A number of scholars have stressed the importance of social workers being apprised of restrictions and exceptions that may be faced by their LGBT clients that are idiosyncratic to their country (Davis, 2013; Moore \& Brainer, 2013). Therefore, it is useful for social workers to be fully informed about gay and lesbian adoption policies in the country in which they practice, since policies may vary widely. Social workers advocating for their LGBT clients may encounter important hurdles. For example, male parents versus female parents may encounter more resistance to adoption in some context. This may be further compounded by demographics including ethnicity, religion, and socioeconomic status. All these factors can play a central role as to how social workers will deliver services.

Group 4 countries have legalized same-gender adoption without any restrictions. It is critical that social workers remain ever vigilant on two fronts: First, monitoring adoption agencies that seek to give preferential treatment to heterosexual couples in the adoption process, and second, countering the ongoing efforts in several countries to reverse the legalization of same-gender adoption. It is imperative that social workers remain organized and vocal in their opposition to attempts to reverse these hard-fought adoption rights. Social workers should continue to inform themselves about same-gender adoption, since little research exists in this field. Social workers should also educate their samegender clients about their rights to adopt, and introduce them to other clients who have previously gone through this challenging process.

\section{Summary}

It has taken over half a century for the United Nations Human Rights Council to pass its first ever resolution protecting the rights of lesbians, gays, bisexuals, and transgender persons. This resolution seeks to protect the equal rights for all, regardless of sexual orientation. Even with these modest inroads, Russia, a powerful nation, has approved a $\$ 3,000$ fine for any Russian citizen advocating for homosexual rights, as noted 
previously. In addition, Russia has halted all adoptions to countries which allow samegender adoption. This is particularly significant since according to UNICEF, nearly 750,000 Russian children await adoption while only 18,000 Russian citizens express interest in adopting. Given their training and expertise, social workers are in a unique position to advance the basic rights of the LGBT community worldwide.

\section{References}

Adoption and same-sex couples: Types of adoption. (2013). Retrieved from http://family.findlaw.com/adoption/adoption-and-same-sex-couples-types-ofadoption.html

American Psychological Association. (2010). Adopted children thrive in same-sex households, study shows. Washington, DC: Author.

Amnesty International: LGBT attacks in Africa on rise. (2013, June 25). Retrieved from http://www.upi.com/Top_News/World-News/2013/06/25/Amnesty-InternationalLGBT-attacks-in-Africa-on-rise/UPI-27711372165874/

Anderssen, N., Amlie, C., \& Ytteroy, E. A. (2002). Outcomes for children of lesbian or gay parents: A review of studies from 1978 to 2000. Scandinavian Journal of Psychology, 43(3), 335-351.

Begley, S. (2013, October 18). First gay adoption approved in France. Time World [Online]. Retrieved from http://world.time.com/2013/10/18/first-gay-adoptionapproved-in-france/

Biblarz, T. J., \& Savci, E. (2010). Lesbian, gay, bisexual and transgender families, Journal of Marriage and Family, 72, 480-497.

Bos, H., Gartrell, N., \& van Gelderen, L. (2013). Adolescents in lesbian families: DSMoriented scale scores and stigmatization. Journal of Gay \& Lesbian Social Services, 25(2), 121-140.

Bos, H., Gartrell, N., Peyser, H., \& van Balen, F. (2008). The USA National Longitudinal Lesbian Family Study (NLLFS): Homophobia, psychological adjustment, and protective factors. Journal of Lesbian Studies, 12, 455-471.

Bos, H., Gartrell, N., Roeleveld, J., \& Ledoux, G. (2013). Civic competence of Dutch children in female same-sex parent families: A comparison with children of oppositesex parents. Youth Society [Online]. Retrieved from http://yas.sagepub.com/content/early/2013/09/09/0044118X13502366.abstract

Brief presented to the Legislative House of Commons Committee on Bill C38 by the Canadian Psychological Association. (2005, June 2). Retrieved from http://www.cpa.ca/cpasite/userfiles/Documents/advocacy/brief.pdf

Brodzinsky, D. (2003). Adoption by lesbian and gays: A national survey of adoption agency policies, practices, and attitudes. New York: Evan B. Donaldson Adoption Institute. 
Brodzinsky, D. (2005). Psychological issues in adoption, research, and practice. London: Oxford University Press.

Burstein, P. (2003). The impact of public opinion on public policy: A review and an agenda. Political Research Quarterly, 56, 29-40.

Canadian Psychological Association. (2006). Marriage of same-sex couples-2006 position statement. Ontario: Author.

Cassell, H. (2013, February 21). Austrian couple wins landmark adoption case. Bay Area Reporter [Online]. Retrieved from http://ebar.com/news/article.php?sec $=$ news \&article $=68536$

Catholic adoption agency seeks exemption on gay adoption regulations. (2010, March 3). The Times of London [Online]. Retrieved from http://www.thetimes.co.uk/tto/faith//

Catholic adoption agency will shut down instead of letting gay couples adopt. (2011, May 29). Retrieved from http://www.patheos.com/blogs/friendlyatheist/2011/05/29/catholic-adoption-agencywill-shut-down-instead-of-letting-gay-couples-adopt/

Chan, R. W., Raboy, B., \& Patterson, C. J. (1998). Psychosocial adjustment among lesbian and heterosexual parents: Associations with children's adjustment. Journal of Family Psychology, 69, 402-419.

Cianciaruso, L. B. (2013). Culturally competent care for nontraditional family structures. Osteopathic Family Physician, 5, 217-224.

Cody, E. (2013, February 13). French same-sex marriage, gay adoption law advances. Boston Globe [Online]. Retrieved from http://www.bostonglobe.com/news/nation/2013/02/13/same-sex-marriage-gayadoption-law-advances-france/PetG8RG5QILmk0rsFiO45L/story.html

Council for Global Equality. (2011). Countries where homosexuality is criminalized. Retrieved from http://www.globalequality.org/component/content/article/166

Creswell, J. W. (2013). Research design: Qualitative, quantitative, and mixed methods approaches $\left(4^{\text {th }}\right.$ ed.). Thousand Oaks, CA: Sage.

Davis, M. A. (2013). Demographics of gay and lesbian adoption and family practice. International Handbooks of Population, 5, 383-401.

de Ruggiero, G. (1977). History of European liberalism. Gloucester, MA: Peter Smith Publishers.

Department of Education. (2011). Adoption: National minimum standards. Cheshire, UK: Author. Retrieved from http://www.crin.org/docs/Adoption-NMS.pdf

Dougherty, J. (2011, June 17). U.N. council passes gay rights resolution. CNN Word [Online]. Retrieved from http://www.cnn.com/2011/WORLD/europe/06/17/un.lgbt.rights/ 
Doughty, S. (2011, January 31). Homosexual couples make fine parents and prejudice is harming children, says Barnardo's boss. Retrieved from http://www.dailymail.co.uk/news/article-1351993/Prejudice-gay-parenting-cuttingchances-children-care-adopted-says-new-Barnados-boss.html

English, R. (2012, November 3). Upper Tribunal confirms illegality of Catholic charity's ban on same-sex couple adoption. Retrieved from http://ukhumanrightsblog.com/2012/11/03/upper-tribunal-confirms-illegality-ofcatholic-charitys-ban-on-same-sex-couple-adoption/

Erich, S., Leung, P., \& Kindle, P. (2005). A comparative analysis of adoptive family functioning with gay/lesbian and heterosexual adoptive parents and their children. Journal of GLBT Family Studies, 1(4), 43-60.

Erich, S., Leung, P., Kindle, P., \& Carter, S. (2005). Gay and lesbian adoptive families: An exploratory study of adoptive family functioning, adoptive child's behavior, and familial support networks. Journal of Family Social Work, 9(1), 17-32.

Europe: Gay adoption ruling advances family equality. (2008). Retrieved from http://www.hrw.org/news/2008/01/23/europe-gay-adoption-ruling-advances-familyequality

Filteau, J. (2006, March 13). Catholic Charities in Boston Archdiocese to end adoption services. Catholic News Service [Online]. Retrieved from http://www.catholicnews.com/data/stories/cns/0601456.htm

Flaks, D. K., Ficher, I., Masterpasqua, F., \& Joseph, G. (1995). Lesbians choosing motherhood: A comparative study of lesbian and heterosexual parents and their children. Developmental Psychology, 31, 105-114.

Franklin, S. (2013, June 22). Jurist [Online]. Russia lower house bans adoption by foreign same-sex couples. Retrieved from http://jurist.org/paperchase/2013/06/russias-lower-legislature-bans-adoption-byforeign-same-sex-couples.php

Gessen, M. (2013, June 10). Divorce and the Duma. International New York Times [Online]. Retrieved from http://latitude.blogs.nytimes.com/2013/06/10/putinsdivorce-overshadows-a-mayoral-race-a-protesters-trial-and-a-bigoted-family$\underline{\text { law } / ? \text { r }=0}$

Goldberg, A. E., \& Smith, J. Z. (2013). Predictors of psychological adjustment in early placed adopted children with lesbian, gay, and heterosexual parents. Journal of Family Psychology, 27, 431-442.

Golombok, S., Mellish, L., Jennings, S., Casey, P., Tasker, F., \& Lamb, M. E. (2013). Adoptive gay father families: Parent-child relationships and children's psychological adjustment. Child Development [Online]. Retrieved from http://onlinelibrary.wiley.com/doi/10.1111/cdev.12155/full 
Golombok, S., Perry, B., Burston, A., Murray, C., Mooney-Sommer, J., Stevens, M., \& Golding, J. (2003). Children with lesbian parents: A community study. Developmental Psychology, 39(1), 20-33.

Groves, R. M., Fowler, F. J., Couper, M. P., Lepkowski, J. M., Singer, E., \& Tourangeau, R. (2013). Survey methodology ( $2^{\text {nd }}$ ed.). New York, NY: John Wiley \& Sons.

Heintz, J. (2012, December 28). Russia: Vladimir Putin signs bill banning Americans from adopting Russian children. Huffington Post [Online]. Retrieved from http://www.huffingtonpost.com/2012/12/28/russia-vladimir-putin-adoptionsbill_n_2374291.html

Hlousek, V., \& Kopecek, L. (2010). Origin, ideology, and transformation of political parties: East-Central and Western Europe compared. Burlington, VA: Ashgate.

Ipsos Global @dvisor. (2013). Same-sex marriage. Retrieved from http://www.ipsosna.com/download/pr.aspx?id=12795

Ipsos Public Affairs. (2013). Credibility intervals for online polling. Retrieved from http://ipsos-na.com/d1/pdf/research/public-affairs/IpsosPA_CredibilityIntervals.pdf

Kenworthy, L. (2009). The effect of public opinion on social policy generosity. SocioEconomic Review, 7(4), 727-740.

Kirchner, E. J. (1999). Liberal parties in Western Europe. London: Cambridge University Press.

Kyle, S. J. (2013, March 12). Catholic Charities: Adoptions “imperiled” by Colo. bill. USA Today [Online]. Retrieved from http://www.usatoday.com/story/news/nation/2013/03/12/catholic-charities-adoptioncivil-unions/1983337/

Leroux, R. (2011). Political economy and liberalism in France: The contributions of Frederic Bastiat. Florence, KY: Routledge.

Levine, S. (2013). Human Rights Campaign: Adoption options overview. Retrieved from http://www.hrc.org/resources/entry/adoption-options-overview

Logan, J., \& Sellick, C. (2007). Lesbian and gay fostering and adoption in the United Kingdom: Prejudice, progress and the challenges of the present. Social Work and Social Sciences Review, 13(2), 35-47.

Moore, M. R., \& Brainer, A. (2013). Race and ethnicity in the lives of sexual minority parents and their children. In A. E. Goldberg \& K. R. Allen (Eds.), LGBT-parent families: Innovations in research and implications for practice (pp. 133-148). New York, NY: Springer.

Moravcsik, A. (1995). Explaining international human rights regimes: Liberal theory and Western Europe. European Journal of International Relations, 1(2), 157-189.

Muslims and Sikhs back church on same-sex marriage. (2012, March 20). Catholic Herald [Online]. Retrieved from 
http://www.catholicherald.co.uk/news/2012/03/20/muslims-and-sikhs-oppose-samesex-marriage/

National Association of Social Workers. (2012). Social work speaks: National Association of Social Workers policy statements, 2012-2014. Washington, DC: NASW Press.

Patterson, C. J. (2008). Children of lesbian and gay parents. Child Development, 63, 1025-1042.

Perrin, E. C. (2013). AAP policy: No relationship between parents' sexual orientation and children's well-being. American Academy of Pediatrics News, 34, 4.

Same-sex "marriage" law forces D.C. Catholic Charities to close adoption program. (2010, February 17). Retrieved from http://www.catholicnewsagency.com/news/samesex marriage law forces d.c. catholic charities to close adoption program/

Samuel, Z. (2010). In practice: Adoption for gay and lesbian couples. Family Law, 40, $1220-1222$.

Seal, R. (2009, October 24). The rise of the gay dad. The Observer [Online]. Retrieved from http://www.theguardian.com/lifeandstyle/2009/oct/25/gay-adoption-fathersparenting

Short, E., Riggs, D. W., Perlesz, A., Brown, R., \& Kane, G. (2007). Lesbian, gay, bisexual, and transgender parented families: A literature review. Melbourne: Australian Psychological Society.

Silver, N. (2013, March 26). How opinion on same-sex marriage is changing, and what it means. The New York Times [Online]. Retrieved from http://fivethirtyeight.blogs.nytimes.com/2013/03/26/how-opinion-on-same-sexmarriage-is-changing-and-what-it-means/? $\mathrm{r}=0$

Tasker, F., \& Golombok, S. (1995). Adults raised as children in lesbian families. American Journal of Orthopsychiatry, 65(2), 203-215.

Ultimate gay adoption guide. (2013). Retrieved from http://adoption.laws.com/gayadoption

United Nations Human Rights. (2013). Fact sheet: Criminalization. Retrieved from https://unfe-uploads-production.s3.amazonaws.com/unfe-34-UN Fact Sheets v6 Criminalization.pdf

Veldorale-Brogan, A., (2012). Adaptation to parental gender transition: Stress and resilience among transgender parents and their children. Electronic Theses, Treatises, and Dissertations. Paper 5247.

Wainwright, J., Russell, S. T., \& Patterson, C. J. (2004). Psychosocial adjustment, school outcomes, and romantic relationships of adolescents with same-sex parents. Child Development, 75, 1886-1898. 


\section{Author note}

Darrel Montero, Ph.D., was Associate Professor and Director, Office of Latino Projects, School of Social Work, Arizona State University. Sadly, he passed away on September 17, 2014 after this article was accepted. Address correspondence to his daughter, Laura Montero, 2781 W. MacArthur Blvd. \#B104, Santa Ana, CA 92704. 